MARION BOWMAN

\title{
Power Play
}

\section{Ritual Rivalry and Targeted Tradition in Glastonbury}

\section{Introduction}

Glastonbury, a small town in the south-west of England, is considered significant by a wide variety of spiritual seekers, including Christians of various denominations, pagans, Druids, Goddess devotees, self-styled 'New Agers', Buddhists, Sufis, earth energies researchers, healers and others who feel that they have in some way been 'called' or 'drawn' to the town (Bowman 1993, 2005; Prince and Riches 2000; Draper 2002; Ivakhiv 2001). Although, for the most part, groups and individuals of very different religious persuasion co-exist comparatively peacefully and a largely laissezfaire attitude to pluralism has developed in the town, increasingly some rivalries and differences in worldview are being played out publicly in 'traditional' forms such as processions, rituals and calendar customs (activities which occur once a year, or according to fixed cycles of time).

While such traditional religious means are used on occasion to express concord rather than conflict, proclaiming and reclaiming are very much part of the ethos of ritual and processional activity in Glastonbury at present, with pageantry and calendar customs regarded as valuable tools in establishing presence and priority in both overt and subtle ways. The extent to which rival claims to territorial and spiritual supremacy are being played out in the (re)creation of rituals and other forms of public display are examined here briefly through two sets of case studies which feature vernacular religious forms being used in relation to contemporary spirituality. The first set involves the Christian Glastonbury Pilgrimage processions and their pagan counterpart the Goddess in the Cart Procession; the second involves the Glastonbury Thorn Ceremony and the Chalice Well Winter Solstice Celebration. Although I have written in considerably greater detail about both the processions and the Thorn Ceremony elsewhere (Bowman 2004, 2006), I focus here on the comparative and tactical aspects of these events. It is worth noting, however, in relation to both case 
studies that although current usage of such forms is of primary interest, it is clear that there is continuity as well as change in the way in which ritual and custom are being strategically employed.

\section{Case Study 1: The Glastonbury Pilgrimage and The Goddess in the Cart Procession}

As I have argued elsewhere (Bowman 2000), although often cast as the 'mainstream' against which 'alternative' spirituality is measured, Christianity in Glastonbury has long been characterised by 'views and practices of religion that exist among the people apart from and alongside the strictly theological and liturgical forms of the official religion' (Yoder 1974: 14).

For many Christians past and present, the attraction of Glastonbury has been its claim to be the 'cradle of English Christianity', where, according to legend, Joseph of Arimathea (the person who provided a tomb for Jesus after the crucifixion) established the first Christian church in the British Isles. On arrival in Glastonbury, Joseph is said to have thrust his staff into the ground at Wearyall Hill; this staff took root and became the Glastonbury thorn, which flowers twice a year, in spring and around Christmas.

Even more significantly, due to a complicated set of extrapolations from the St Joseph legend, some believe that Jesus himself visited Glastonbury and that he may even have spent some of the time before he commenced his ministry living there (Bowman 2003-4). By the Middle Ages, Glastonbury Abbey was a major pilgrimage centre, boasting a huge collection of relics and a fine library, and a Lady Chapel allegedly built on the site of Joseph's original church. The Abbey was brutally suppressed at the time of the Reformation, with the elderly Abbot Richard Whiting and two monks being dragged through the town and hanged on the Tor, the strangely contoured hill that rises above Glastonbury. Although Glastonbury Abbey fell into private hands and was left to ruin, in 1908 ownership passed to the (Anglican) Bath and Wells Diocesan Trust (Carley 1996: 175) and the Abbey, whose grounds dominate the centre of the town, is administered as an historical site.

Glastonbury's Christian past and its historical significance are celebrated in the annual Glastonbury Pilgrimage, centred on the Abbey ruins. For one weekend each summer, on Saturday there is the Anglican Pilgrimage and on Sunday the Roman Catholic Pilgrimage, perhaps the most superficially 'traditional' or conventional processions in Glastonbury. Although for the sake of clarity I refer to the Anglican Pilgrimage and the Catholic 
Pilgrimage, both refer to themselves as the Glastonbury Pilgrimage. While for participants the culmination of the day is the service in the Abbey grounds, the most public aspects are the processions.

In 1908, to celebrate the purchase of the Abbey, after a procession from the Anglican St John the Baptist Church on the High Street, a service of thanksgiving was held in the Abbey grounds. In 1926 the West of England Pilgrimage Association was founded, and Anglican pilgrimage processions between St John's Church and the Abbey grounds have taken place more or less continuously since the 1930s (Hext 2004). As Anglicans involved in the Pilgrimage tend to be Anglo-Catholic or 'High' Church of England, and because there is an Orthodox Christian presence at the Pilgrimage, the Anglican Pilgrimage does not allow female clergy to participate, despite the ordination of women priests in the Church of England for over a decade. As a result of this decision, St John's Church felt unable to participate in the Pilgrimage and participants no longer robe within and process out of the church. This situation was further exacerbated by the appointment in 2002 of a female vicar St John's. While some Glastonians are involved, many outsiders come to the Pilgrimage. In the Anglican Pilgrimage, a statue of the Virgin Mary is carried, banners from the participating churches are displayed, hymns are sung, and a grand array of male clerical ceremonial garb is on display during the short procession down the High Street and into the Abbey grounds.

Meanwhile, across the road from the Abbey ruins, stands the present Roman Catholic St Mary's Church and the Shrine of Our Lady of Glastonbury. Perhaps not surprisingly, St Mary's claims continuity with pre-Reformation Glastonbury and describes its shrine as 'a successor to the ancient Shrine of Our Lady of Glastonbury'. The Tor is the starting point of the Catholic pilgrimage, in memory of Abbot Whiting and the two other monks who were hanged there at the time of the Dissolution, and the climax of the Pilgrimage is Mass in the Abbey grounds. While there are visually similar aspects between the Anglican and Catholic pilgrimage processions - the carrying of the statue of Our Lady of Glastonbury, the display of banners, the singing of hymns and an obvious hierarchy of male clerics - significantly more of the town is encompassed by the Catholic pilgrimage than the Anglican one, from the ruined chapel of St Michael on the Tor, through town to the Abbey ruins. While many outsiders do come to the Catholic Pilgrimage, there seems to be a much greater degree of local participation.

Since the 1980s the Catholic Pilgrimage has been held on the same weekend as the Anglican Pilgrimage, mixing ecumenism and practicality as the 


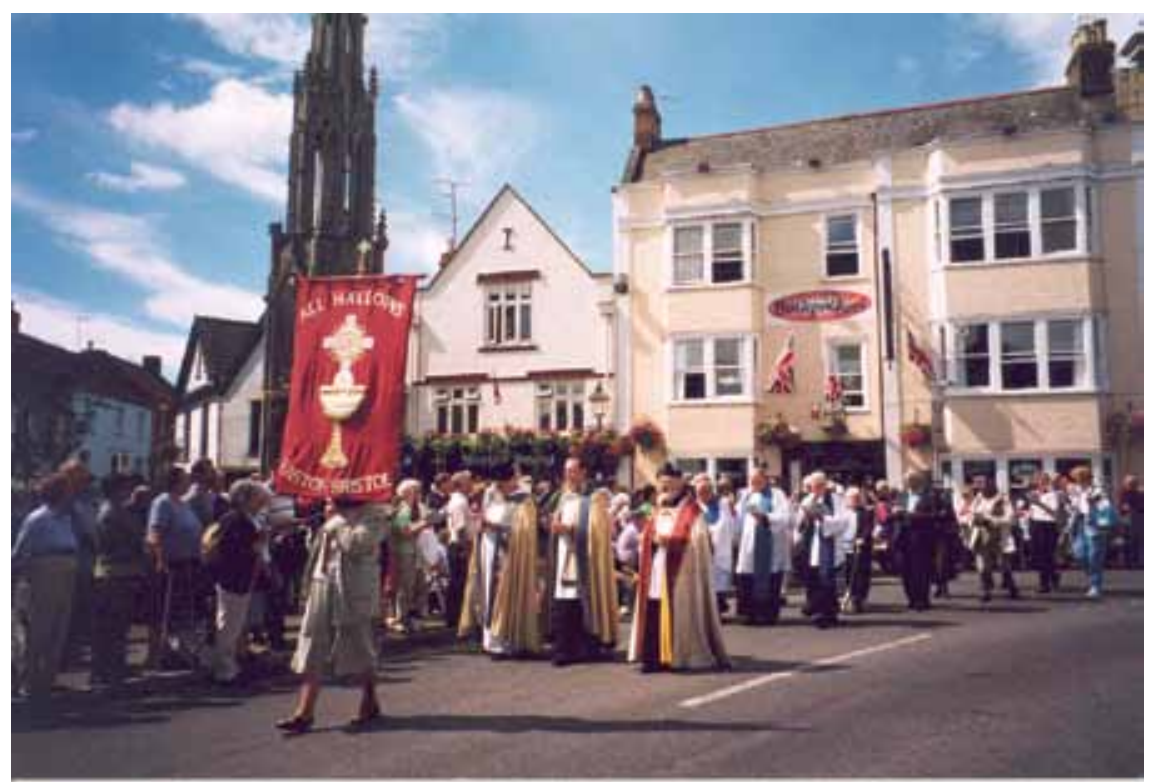

The Anglican pilgrimage in Glastonbury. Photo by Marion Bowman.

costs of hiring facilities can be shared, and a supermarket was built on the site formerly used by the Catholic Pilgrimage for their open-air Mass. Many have seen the weekend of pilgrimage as a positive development for ecumenism, and there was a particular irony in 2003, when the Rev. Maxine Marsh, the female vicar of St John's (who cannot take part in the Anglican Pilgrimage) was invited to participate in the Catholic Pilgrimage as a symbol of Christian unity.

On the one hand, the Glastonbury Pilgrimage events - and in particular the processions - underline the theological and historical differences between Christians who commemorate the past and, by extension, view the present through rather different denominational lenses. Furthermore, the Anglican Pilgrimage highlights the current strains and divisions within the Church of England over female ordination, and is now physically and doctrinally estranged from the Anglican Church in Glastonbury. On the other hand, however, it is important to understand that in recent decades, when Christianity has appeared embattled in relation to the great variety of 'alternative' spiritual activity that has been taking place in Glastonbury since the 1970s onwards, the Pilgrimages have functioned as an important means for Christianity to reassert its place in and claim on Glastonbury. Together, these two pilgrimages have been reclaiming Glastonbury for 
Christianity, and the processions in particular have been the vehicle for a large, public band of Christians to commemorate Christianity first taking root in England and to celebrate the town's Christian heritage and identity.

However, since 1996, there has been considerable additional processional activity, connected with the annual Glastonbury Goddess Conference, and I now turn to the development of this 'tradition', its fluid nature and the different agendas addressed in the Goddess in the Cart Procession.

Many devotees of the Goddess believe that Glastonbury was significant focus of Goddess spirituality in pre-Christian times, and that the Abbey was deliberately sited on the cultic centre in an attempt to obliterate devotion to her. Since 1996 the Glastonbury Goddess Conference has been held around what is considered the 'Celtic' festival of Lammas/Lughnasa (1 August). Although the conference organisers and many participants are Glastonbury based, the majority of conference attendees are outsiders, coming from all over the UK, as well as Scandinavia, the Netherlands, America and Australia.

Inspired by 'an old Celtic image' of a cart with huge wheels containing an image of the Goddess, the Conference co-organiser Kathy Jones had the idea of the 'Goddess in the Cart Procession', in which an image of the Goddess would be pulled through the streets of Glastonbury, (re)establishing her presence in the town. Over the years this procession has developed in a variety of ways, with changes and expansions in the ground covered - physically and metaphorically - by the Goddess effigies.

Jones likes the idea of 'beating boundaries', and from the start she has seen the procession as 'claiming space', as a way of saying that 'this belongs to Her'. The Goddess Procession used to take a less public route, but since 2000 it has gone 'sunwise', leaving from the Town Hall (which is just beside the entrance to the Abbey), up the High Street past St John's Church, 'circumambulating the Abbey', to the Tor. It is now, in effect, a mirror image of the Christian Pilgrimage processions, in particular the Catholic Pilgrimage procession which starts from the Tor and proceeds to the Abbey. The Goddess in the Cart Procession started as a procession through the streets of Glastonbury and up the Tor, originally with a large effigy of the Goddess constructed at the conference pulled in a cart. Each year in rotation a model of the maiden, the mother or the crone goddess was made for the procession on the last day of the conference, the Sunday, the most public aspect of the event. However, after the cart was stolen, smaller wicker goddess figures, light enough for an individual or two people to carry, were made instead. In recent years the procession has also featured large colourful banners depicting a range of female deities, including Cel- 


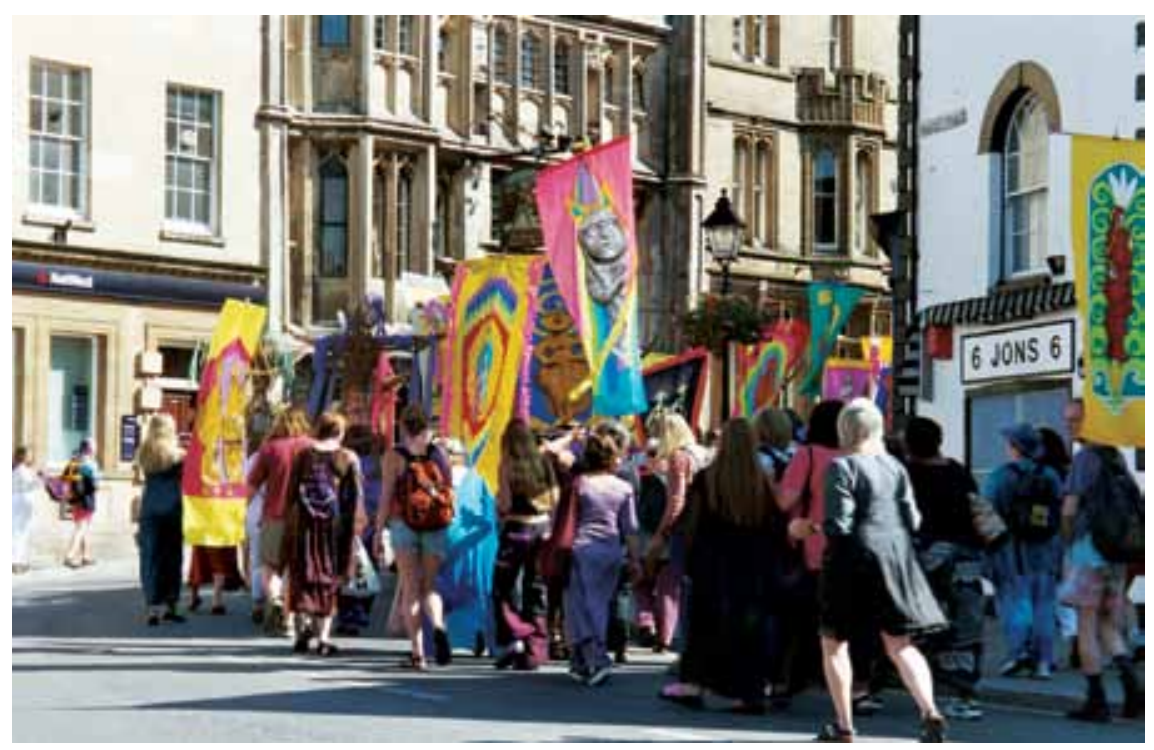

The Goddess in the Cart Procession going up Glastonbury High Street - a mirror image of the Christian Pilgrimage processions. Photo by Marion Bowman.

tic, Egyptian, Near Eastern, Greek, Roman, Indian, African and other indigenous goddesses, Bodhisattvas in female form and the Virgin Mary. Processions are lively, colourful and noisy, with chants and songs familiar in Goddess spirituality, as well as those developed at the conferences.

With the establishment of the Glastonbury Goddess Temple in 2002 and a Priestess training programme, the Goddess movement's rivalry with Christianity continued to develop. Having created a mirror image of the Christian pilgrimage processions and, through the banners, incorporated the Christian Virgin Mary into the Goddess in the Cart Procession, the 2004 Conference events further exemplified both the flexibility and the politicised agenda of processional activity in Glastonbury, as well as the increasing confidence and ambition of the Goddess movement there. In 2004 the Conference was a celebration of the Goddess Bridie (or Bridget). For the first time, the procession was staged on Thursday, rather than Sunday, making it considerably more noticeable to a greater number of people and taking in more sacred sites than ever. In addition, on the Friday afternoon the image of Bridie was carried to Bride's Mound, a site associated with the Celtic St Bridget, devotion to whom many in Goddess circles believe was a thinly veiled continuation of Goddess worship. The route took the procession past the Catholic church, and past the Holy Thorn, which some 
stopped to decorate. More ground than ever was covered for the Goddess, and further 'Christian' sites reclaimed.

Processions can be used to celebrate and commemorate; to protest and contest; to include and exclude; to display and convey messages and meanings on a variety of levels. Both Christians and Goddess devotees regard Glastonbury as a significant site, and for that reason want to be there in the public, celebratory and assertive manner provided by procession. Both groups creatively utilise the traditional forms of banners, images and song to declare their allegiances. It is probably fair to say that the Goddess processions most self-consciously exploit the fluid nature and visual power of pageantry, and the political/politicised potential of the procession. Nevertheless, as the internal politics of the Glastonbury Pilgrimages demonstrate, such usage is not entirely novel.

\section{Case Study 2: The Glastonbury Thorn Ceremony and the Chalice Well Winter Solstice Celebration}

I have already alluded to one of Glastonbury's most significant Christian myths, that St Joseph of Arimathea's staff became the Holy Thorn which blossoms both in spring and in winter, and this has given rise to a calendar custom, the Holy Thorn Ceremony.

Allegedly a 'revival' of an 'ancient tradition', the Holy Thorn Ceremony in its present form dates from 1929, when it was 'revived' by Rev. Lionel Smithett Lewis, then vicar of St John's and a passionate advocate of Glastonbury's vernacular Christian legends. The 'revival' of the custom gave Lewis a vehicle through which to champion Glastonbury's status as the first church in England and to perpetuate her legends; for him, the Glastonbury Thorn was an 'ever-present testimony to the story of St Joseph' (Lewis 1985: 5). However, his enthusiasm was matched by the scepticism of the then Dean of Wells, Dr Armitage Robinson, who was scathing in his dismissal of the Glastonbury legends, and his disagreement with Lionel Smithett Lewis on that topic was played out publicly in print (see Armitage Robinson 1926, Lewis 1985). ${ }^{1}$ Lewis started the ceremony two years after

1 This is a good example of the unsatisfactory nature of making any simple division between 'folk' and 'official' religion in relation to vernacular tradition; both Armitage Robinson and Lewis were ostensibly representatives of 'official' religion. 
The Holy Thorn on Wearyall Hill, Glastonbury, reputedly on the site of the original. Photo by Marion Bowman.

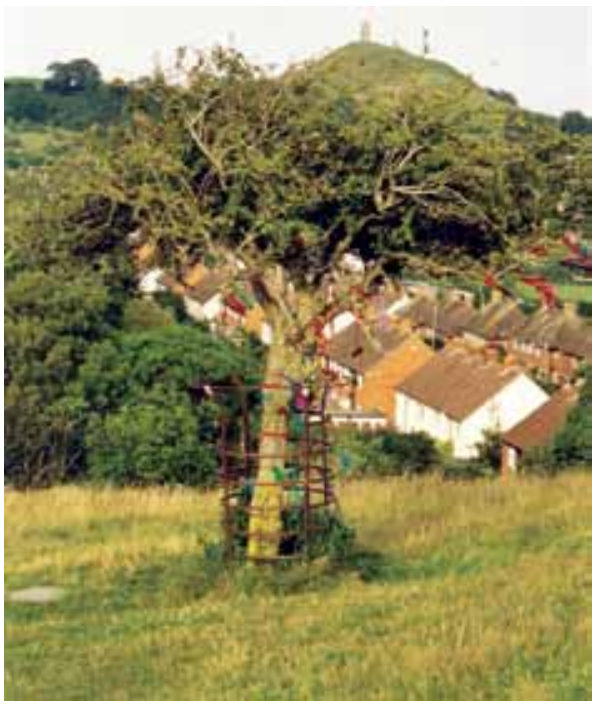

his rebuttal of J. Armitage Robinson in the foreword to the second edition of Glastonbury - The Mother of Saints; Her Saints, AD 37-1539.

The focus of the ceremony is the cutting each December of sprigs from the winter-flowering Holy Thorn outside the Anglican church of St John the Baptist in Glastonbury to be sent to the Queen. (As they are perpetuated by grafting, a number of Holy Thorns are found in Glastonbury in addition to the one allegedly growing on the site of the original on Wearyall Hill and which was badly mutilated by Reformers and Puritans.) The ceremony takes place in the presence of the vicar of St John's and other clergy, the Mayor, members of the town council, children from the Church of England St John's Infants School and some of their parents and other relations. The Thorn is cut by the eldest child at St John's School. At some point in the ceremony, the children sing 'The Holy Thorn' song, retelling the legend of St Joseph of Arimathea bringing the Holy Thorn to Glastonbury.

The Holy Thorn Ceremony has been an event for and about Glastonbury, with resident Glastonian participants, rather than outsiders - as is often the case with the Anglican Pilgrimage, and many of the 'alternative' events that take place in the town. Many of the adults who attend the ceremony as parents, friends or relations of the children participating remember taking part themselves as youngsters, and they tend to be most insistent that it is an 'ancient' custom. It is clear that some parents consider it a great honour for their son or daughter to be given the role of Thorn cutter. Local press 
and television are always in attendance, and photographs of the Thorn cutter, the vicar and the Mayor beside the Thorn tend to appear each year in local papers.

Although at its inception the Holy Thorn Ceremony was in part about the internal politics and the status of Glastonbury's legends, it has been particularly significant since the 1970s as a form of civil religion. Again, it is helpful to remember that from the 1970s many Glastonians were experiencing great discontinuity and upheaval with the decline of the local economy and a great influx of 'alternative', seemingly alien, spiritual activity. The Holy Thorn Ceremony not only reaffirmed Glastonbury's special status as a Christian site, but it also provided a means of expressing and celebrating mainstream values. The letters sent each year by the vicar of St John's to accompany the thorn sprigs constantly affirm the loyalty of the ('real') people of Glastonbury to the Queen.

However, the Holy Thorn Ceremony is now experiencing rivalry both internally and externally, as it were (Bowman 2006). There are Christians who are not comfortable with Glastonbury's vernacular myths and traditions. Furthermore, in 2002, some of the Glastonbury clergy and others involved in 'Christians Together in Glastonbury' decided that it would be appropriate to bless the town's Christmas tree, as a way of 'reclaiming Christmas for Christianity'. This Christmas Tree Blessing seems to be developing into an annual 'tradition', and the event is attended by the Mayor and members of the Council. (One Glastonbury cleric, supportive of the development of greater ecumenical activity and stronger Christian involvement in the wider community, nevertheless remarked wryly, 'What is it about this town that if there's a tree you've got to dance round it?')

Moreover, since 1998, an increasingly elaborate Winter Solstice Celebration has been held at Chalice Well, a chalybeate spring which stains red. Some associate its red (and reputedly healing) water with the Chalice (or Grail) St Joseph of Arimathea is said to have brought with him to Glastonbury, and the blood of Christ, while others regard the waters as the menstrual flow of the Goddess. Chalice Well is situated in a garden maintained by a charitable trust, open to and used by people of all spiritual paths. As a Trustee commented, 'Chalice Well attempts to include all in its activities, but more often than not it ends up offending both the Christians and the pagans!'

In addition to a Solstice fire, the Chalice Well Winter Solstice Celebration features the decoration of the Holy Thorns there. When I asked why the decorating the Holy Thorn was included in the Winter Solstice ceremony, Nicholas Mann (Glastonbury resident, author and Chalice Well Trustee) replied: 
Decorating the Holy Thorn trees in the garden of Chalice Well just seemed the right thing to do at a Winter Solstice celebration. It combined a wide-spread tree decoration custom with a Glastonbury tradition as well as with what we felt to be an ancient recognition of the cycle of the year. (Email communication, 23 December 2005.)

Another person associated with the ceremony saw decorating the Holy Thorn as a parallel to decorating the Christmas tree. Asked how the decoration of the Thorn has been presented in the context of the ceremony, Mann responded:

As an honouring of the tree and of trees in general, as a celebration of the season, and, sometimes but not always-given this is a Glastonbury event-as an honouring of Joseph of Arimathea and of the Christian tradition in Glastonbury (email communication, 23 December 2005).

If the latter comment seems paradoxical, the explanation lies in the ways in which vernacular Christian traditions are perceived and used by many of Glastonbury's spiritual seekers (see Bowman 2000, 2003-4). For those who are convinced that Glastonbury was an important Druidic centre of learning, or who consider it a major centre of earth energies, it seems only natural that St Joseph would have made his way there. Reversing the Christian assumption that Glastonbury is special on account of St Joseph and possibly Jesus having come there, an alternative view is that all sorts of people have been drawn to Glastonbury because it is inherently sacred and special. This typifies the inclusive (as opposed to confrontational) nature of some aspects of contemporary spirituality in Glastonbury. In this context, myths can be recycled and rewoven, traditions can be blended, customs can complement rather than compete.

To return to the issue of 'mainstream' and 'alternative' touched on at the start of this article, a recent survey revealed that roughly one third of Glastonbury's approximately 9,000 residents consider themselves to have had some sort of calling to be in Glastonbury. Some of those who came as spiritual seekers and pilgrims decided to stay and have now settled, many involved in the unique spiritual service industry that has evolved in the town. If the Holy Thorn Ceremony in the latter part of the twentieth century functioned as a form of civil religion in Glastonbury, it is interesting to note that at the 2004 Winter Solstice Celebration, the first person to decorate the Chalice Well Holy Thorn was the Mayor of Glastonbury. It may be that we are seeing in this ritual context a reappraisal of, or at 
least some recognition of a shift in, what might constitute 'mainstream' in Glastonbury for the twenty-first century.

\section{Conclusion}

As scholars from a variety of disciplines and perspectives have observed, ritual and tradition are powerful, multivalent devices that can both convey and generate meaning, and performative rituals such as processions and calendar customs can help to engender feelings of solidarity, community and continuity. As Ian Reader and George J. Tanabe comment, religion is 'a matter not only of doctrine and belief but of participation, custom, ritual, action, practice and belonging' (1998: 5). In Glastonbury, not only are different religious groups developing their own ceremonial cycles and ritual practices, they are also creating traditions in relation to and in reaction to each other, to promote particular versions of the past and visions for the future.

\section{References}

\section{Armitage Robinson, J.}

1926 Two Glastonbury Legends. Cambridge: Cambridge University Press.

\section{Bowman, Marion}

1993 Drawn to Glastonbury. In: Ian Reader, and Tony Walter (eds), Pilgrimage in Popular Culture; pp. 29-62. London: Macmillan.

2000 More of the same? Christianity, Vernacular Religion and Alternative Spirituality in Glastonbury. In: Steven Sutcliffe, and Marion Bowman (eds), Beyond New Age: Exploring Alternative Spirituality; pp. 83-104. Edinburgh: Edinburgh University Press.

2003-4 Taking Stories Seriously: Vernacular Religion, Contemporary Spirituality and the Myth of Jesus in Glastonbury. Temenos 39-40: 125-42.

2004 Procession and Possession in Glastonbury: Continuity, Change and the Manipulation of Tradition. Folklore 115 (3): 1-13.

2005 Ancient Avalon, New Jerusalem, Heart Chakra of Planet Earth: Localisation and Globalisation in Glastonbury. Numen 52 (2): 157-90.

2006 The Holy Thorn Ceremony: Revival, Rivalry and Civil Religion in Glastonbury. Folklore 117 (2): 123-40.

\section{Carley, James P.}

1996 Glastonbury Abbey: The Holy House at the Head of the Moors Adventurous. Glastonbury: Gothic Image Publications. 


\section{Draper, Ian (Mustafa)}

2002 Towards a Postmodern Sufism: Eclecticism, Appropriation and Adaptation in a Naqshbandiyya and a Qadiriyya Tariqa in the UK. Unpublished doctoral thesis. Department of Theology, University of Birmingham.

\section{Hext, John}

2004 The Glastonbury Pilgrimage: A Brief History of the Glastonbury Pilgrimage. http:/ / trushare.com/GLASTONBURY/glashist.htm (accessed 15 March 2004).

Ivakhiv, Adrian J.

2001 Claiming Sacred Ground: Pilgrims and Politics at Glastonbury and Sedona. Bloomington and Indianapolis: Indiana University Press.

\section{Jones, Kathy}

2000 In the Nature of Avalon: Goddess Pilgrimages in Glastonbury's Sacred Landscape. Glastonbury: Ariadne Publications.

\section{Lewis, Lionel Smithett}

1985 Glastonbury - The Mother of Saints; Her Saints, AD 37-1539. 2nd edition. Orpington: Research Into Lost Knowledge Organisation. (First published in 1927)

Prince, Ruth, and David Riches

2000 The New Age in Glastonbury: the Construction of Religious Movements. New York, Oxford: Berghahn Books.

Reader, Ian, and George J. Tanabe, Jr.

1998 Practically Religious: Worldly Benefits and the Common Religion of Japan. Honolulu: University of Hawaii Press.

\section{Yoder, Don}

1974 Toward a Definition of Folk Religion. Western Folklore 33 (1): 2-15. 